\title{
Identification of Slip Surfaces Using the Geoelectric Imaging Method in the Kalirejo Area, Kokap District, Yogyakarta, Indonesia
}

\author{
Rizqi Prastowo ${ }^{1}$, Hurien Helmi ${ }^{2}$, Obrin Trianda ${ }^{3}$, Rofiqul Umam ${ }^{4}$ \\ Institut Teknologi Nasional Yogyakarta, Indonesia ${ }^{1,2,3}$, Kwansei Gakuin University, Japan ${ }^{4}$ \\ rizqi@itny.ac.id ${ }^{1}$, hurien.helmi@itny.ac.id ${ }^{2}$, obrin@itny.ac.id ${ }^{3}$, egk71822@kwansei.ac.jp ${ }^{4}$
}

Received: November $23^{\text {rd }}, 2020$. Revised: March $29^{\text {th }}, 2021$. Accepted: April $23^{\text {rd }}, 2021$

\section{Keywords :}

Landslide; Slip Surface;

Resistivity; Kokap

\begin{abstract}
Landslides are a significant threat to the environment, infrastructure, and human activity, especially in mountainous and hilly areas. It is, therefore, important to accurately identify the social movements that trigger these processes. The resistivity method can investigate subsurface geological variations, including the potential for landslides. This research was conducted to investigate the subsurface structures in the Kalirejo Village area, Kokap District, Kulon Progo Regency, Yogyakarta regarding identifying the sliding location. This investigation includes five lines of tomographic geoelectric measurements. The results show that the slips surface is at a depth of about 5-10 $\mathrm{m}$ with a high resistivity value and the landslide material is weathered soil, and the slip surface is andesite. The resistivity of andesite in range 668-1600 $\Omega \mathrm{m}$. The landslide material's thickness is around 5-8 $m$ with resistivity in the range 4,01-22.1 $\Omega \mathrm{m}$. Landslide material is water-saturated soil.
\end{abstract}

\section{INTRODUCTION}

Landslides are a natural occurrence resulting in the loss of life and socio-economic losses [1]. Landslides and slopes are primarily associated with hilly areas and are restricted to urban areas in essence. Development in tourism and residential activities is still rampant in these regions. Various variables, including topography, atmosphere, geology, and land use, account for the prevalence of failures. Some nations have similar soils but different precipitation or equivalent rainfall patterns, but other land services [2]. Landslides often occur in Yogyakarta, causing the community to damage, especially in the northern part of the Kulonprogo Regency, namely the Kokap District. Based on the PVMBG (Center for Volcanology for Disaster and Geological Mitigation) classification, Kokap Subistrict is categorized as a district with medium-high landslide vulnerability potential [3]. A landslide occurred on 27 October 2020 that resulted in landslides hitting three houses in Plampang 2, Kalirejo Village, Kokap District, Kulon Progo Regency, Yogyakarta Special Area (Figure 1) [4].

The increased activity of landslide movements in recent years, their surface range, and the problematic predictability of their activation have triggered considerable interest among local governments, geologists, and scientists. By identifying the causes of landslides, their work aims to minimize the 
losses and damage caused by destructive landslide processes [5] [6]. The most critical problems awaiting a fast solution include studies into tracking mass movements and determining their causes. The multidisciplinary approach to science is focused on several techniques. These techniques allow data to be obtained on the lithology, geotechnical parameters, and hydrogeological conditions of the rock layers underlying them. Therefore, other techniques, especially geophysical methods, prove to be helpful in this matter. They allow continuous substratum floor identification and are relatively inexpensive [7] [8] [9].

The use of geophysical methods in determining internal landslide structure has increased with the advent of geophysical equipment automation, digital data storage, and the perfecting of processing and interpretation procedures [10] [11]. The electrical resistivity method generates a map of the distribution of subsoil electrical resistivity, a geophysical parameter sensitive to the nature of the material (especially clay content), water content and electrical conductivity, and rock weathering and fracturing [12]. Resistivity comparison, which shows a difference in texture and porosity, may be used to show the state of the foundation, the sliding plane, and the form of a landslide that may occur [13]. Many factors that affect slope stability, such as hydrologic conditions, bedrock type, soil type, and soil thickness, also affect rock and soil electrical resistance [14]. Identifying the position of the failure zone, slope morphology contrasts in lithology and soil types, moisture regimes, and shifts in moisture over time using electrical resistivity system profiles has proven helpful for landslide investigations [1] [15] [16]. Other methods of collecting knowledge about landslide features and slope conditions, such as drilling exploration, are often expensive and time-consuming geotechnical ventures [12]. Electrical resistivity is the most commonly used and potent tool in this study [7] [15]. The results obtained using this method make it possible to determine the lithological sequences, to reconstruct the lateral extension and thickness of the soil, to determine the internal structure of landslides, to identify the possible slip planes, to determine the sliding surfaces between the slide material and the underlying bedrock, to estimate the dynamic conditions of the groundwater [7] [16] [17]. In the kalirejo region, geophysical mitigation efforts were carried out, namely by microtremor process, and geological survey results show possible landslide disasters in the landslide movement of the Kalirejo area andesite dominated derailment sector [18].

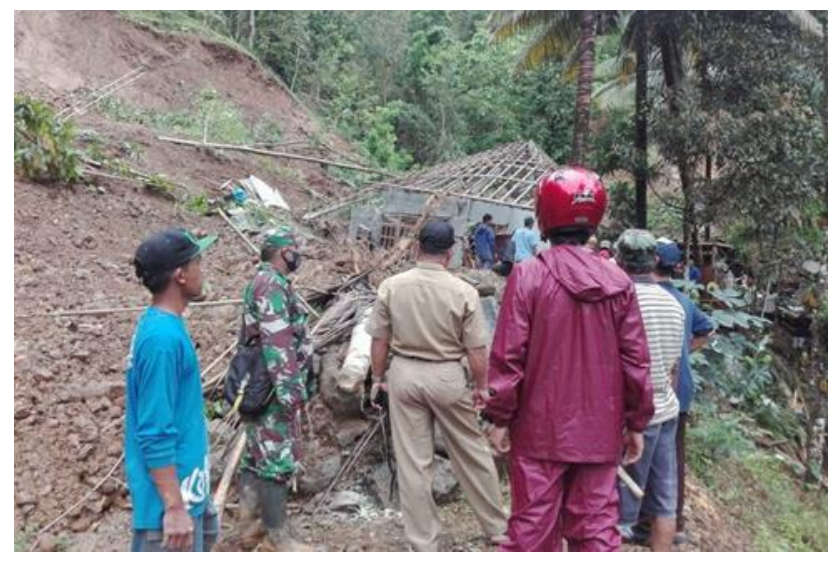

Fig 1. The landslide was damaged a house near Kalirejo Village

Geologically, Interpretation of Kulon Progo Mountains as large domes with flat peaks and steep slopes. This dome's core consists of three old andesite volcanoes whose former magma chambers are now exposed [19]. Mount Gajah, located in the middle of the dome, is the two oldest volcanoes that produce basaltic andesite hypersthenic augite. Mount Ijo produces basaltic andesite pyroxene. Mount Menoreh is the youngest volcano to make hornblende andesite august. Determination of 6 formation units in the Kulon Progo Mountains from old to young, namely: Middle-Oligocene Nanggulan Formation, Kaligesing Formation, Dukuh Formation, Middle Miocene Jonggrangan Formation, Middle-Late Miocene Sentolo Formation, and Alluvium [20]. The geological observations indicate that the study area is dominated by andesite, as shown in Figure 2. 


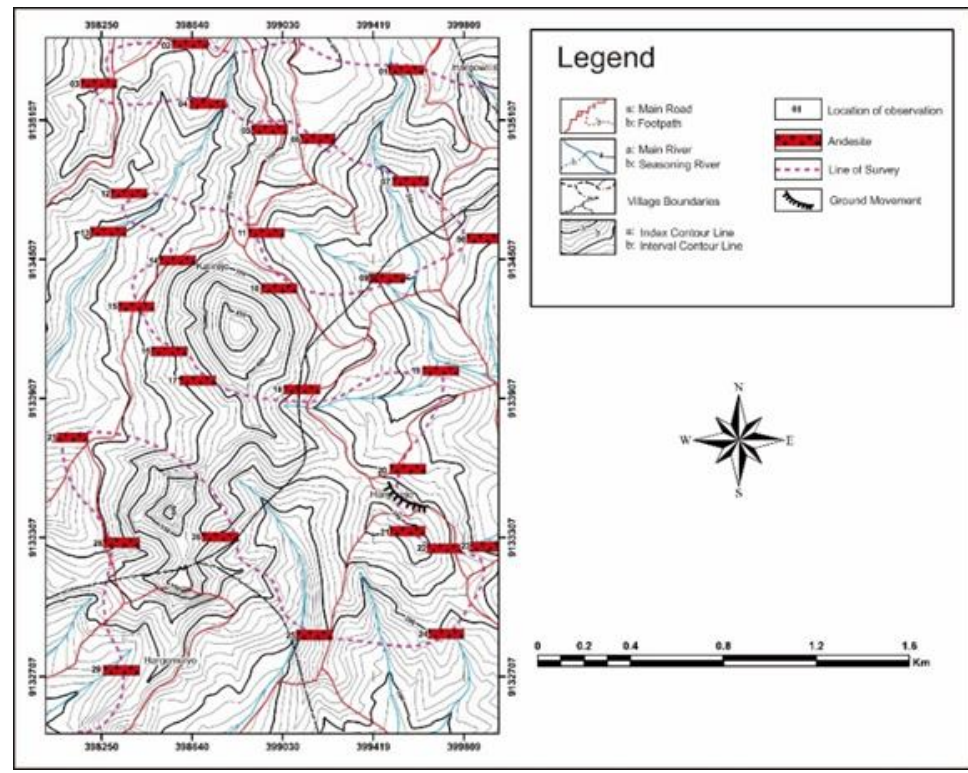

Fig 2. Map showing the distribution of andesite outcrops in the study area

A geophysical survey using the resistivity method in the Penggung Purwosari Village area of Girimulyo, Kulonprogo Yogyakarta in Indonesia, revealed a resistivity value of $9 \mathrm{Ohm}$ defines the first layer, interpreted as soil saturated with water in the form of surface soil. The second layer is interpreted as a water-unsaturated soil layer with a resistivity value of 9-36 Ohm [21]. Even though the study area's bedrock is dominated by andesite, this can be used as a guideline that the subsurface conditions are close to those in the study area. To maximize the slip plane slope's determination, the geoelectric approach with a dipole-dipole configuration must be combined with a geotechnical survey [13] [22].

\section{METHOD}

The implementation of field research activities was carried out in the Kalirejo village area, Kokap District, Kulonprogo Regency, Yogyakarta. Implementation of the initial phase of activities in the form of secondary data collection in the form of a regional geological map of the Yogyakarta sheet and an initial geological survey to determine the resistivity survey location. This research was conducted with surface and subsurface mapping methods, namely by describing and classifying rock types based on geology and rock resistivity (figure 3). Based on the mapping results, there is one rock unit in the form of an andesite. Based on the slope analysis data, four percentages of the slope value are obtained, namely: low slope $\left(0^{\circ}-15^{\circ}\right)$, medium slope zone $\left(16^{\circ}-30^{\circ}\right)$, high slope zone $\left(31^{\circ}-40^{\circ}\right)$, and very high slope zone $\left(>41^{\circ}\right)$. Based on the structural data on the surface, a Buffer Structure Map is made to determine the distance and density of a structure, obtained five categories: $<100,100-200$, 200-300, 300-400, and > 400. Developing land use consists of four, namely: Gardens, Settlements, Rainfed Rice, and Tegan. Based on the data above and an overlay of several existing maps, we can obtain three soil vulnerability zones in the research area: Low ground movement vulnerability zone, medium soil movement vulnerability zone, and high ground motion susceptibility zone. The researcher refers to creating a geoelectric path to determine the ground motion zone's distribution and slip plane from the three zones obtained. The geoelectric approach is a geophysical technique used to examine horizontal and vertical discontinuities in the ground's electrical properties and to detect threedimensional bodies of anomalous resistivity [21]. Resistivity measurements are made by injecting a controlled electric current into the ground through two steel electrodes and measuring the potential drop at two other electrodes. For geoelectric surveys, electrode arrays such as Wenner, Schlumberger, dipole-dipole, and so on may be used. The apparent resistivity value $(\rho)$ is determined using the injected current $(\mathrm{I})$, the measured potential $(\mathrm{V})$, and a geometric coefficient $(\mathrm{k})$ related to the spatial 
JIPF, Vol. 6 No. 3, September 2021

electrode configuration, as follows: $\rho=\mathrm{kV} / \mathrm{I}[23]$.

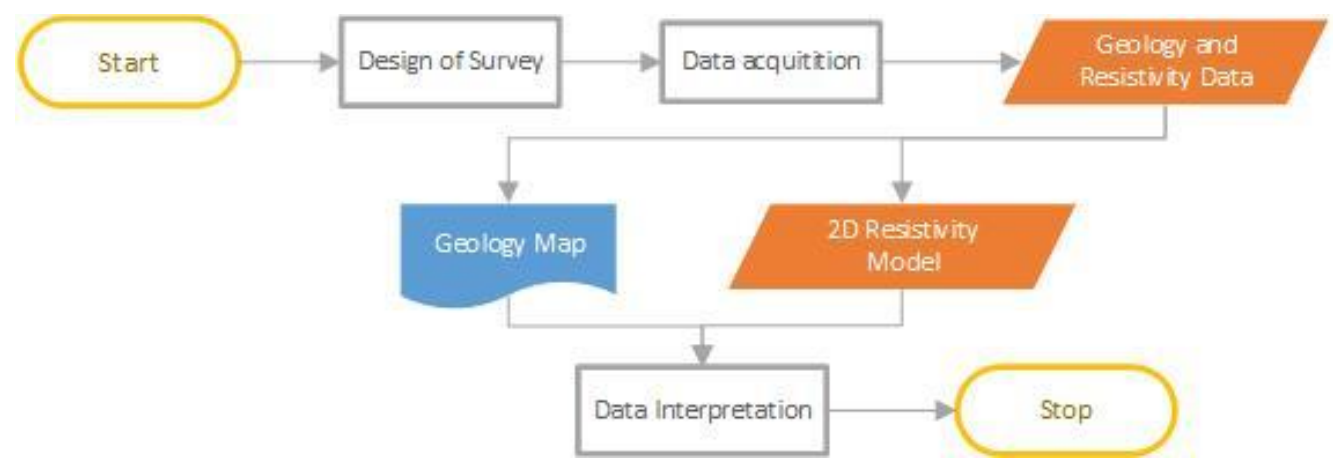

Fig 3. Research flow chart

Geoelectric surveys along the profiles were taken with Dipole-Dipole configurations. Dipole-Dipole configurations provide two dimensions (2D) profiling that shows lithology in the lateral direction. The five lines symbolized by a dot color represent the location and direction of the $2 \mathrm{D}$ lines. Line 3 and 4 are 200 meters long and stretch from south to north, while line 1, 2, and 5 are 200 meters long and extend from west to east. The distance between the potential electrodes moving step by step is as much as $1 \mathrm{n}$ 6. Data processing used RES2DINV software [10]. The map of the survey location can be seen in the following Figure 4.

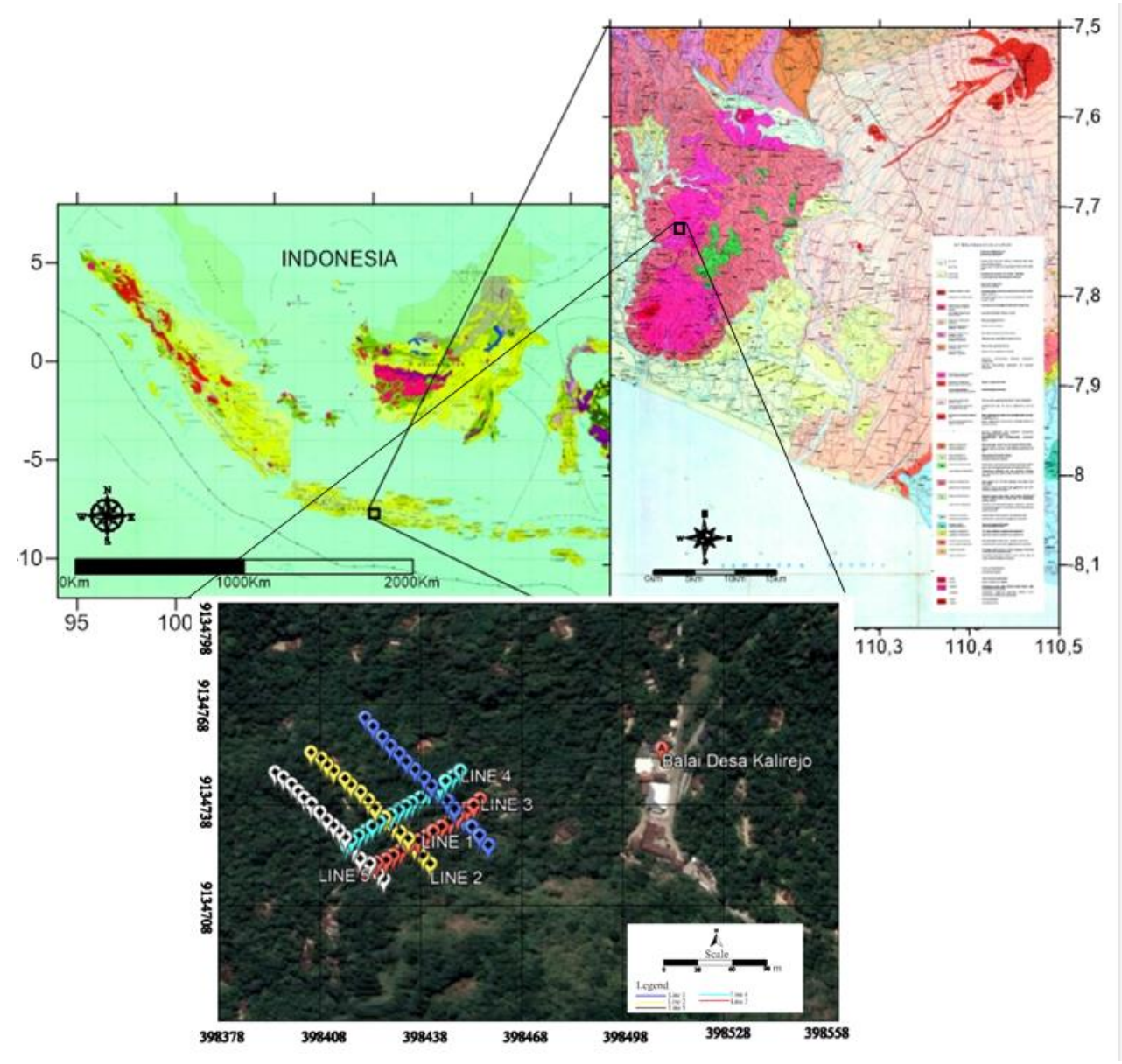

Fig 4. Data acquisition map of the study area 
Identification of Slip Surfaces Using the Geoelectric Imaging Method... Rizqi Prastowo, Hurien Helmi, Obrin Trianda, Rofiqul Umam

\section{RESULTS AND DISCUSSIONS}

Resistivity Survey Line 1 shows a layered contrast, namely soil and impermeable rock (Fig. 5). The first layer is soil / weathered with a resistivity value of 70-140 $\Omega \mathrm{m}$, which is the soil marked with green colour. Meanwhile, the resistivity of $10-45 \Omega \mathrm{m}$ is the soil with water presaturation because the measurement is done the day after it rains. The second layer is an igneous rock in the form of andesite. The igneous rock is impermeable so that it becomes a slip area. The slip plane is at a distance of $100 \mathrm{~m}$ from the starting point and in the descent area from an elevation of $305 \mathrm{~m}$ to $270 \mathrm{~m}$ and at a depth of about 5-10 $\mathrm{m}$. The slip plane is in the form of andesite rock shown in red with a resistivity between 426-800 $\Omega \mathrm{m}$ shown on the dotted black line because of its function, which has less capacity to conduct electricity, the bedrock has elevated resistivity values. In other words, electricity cannot quickly move through it.

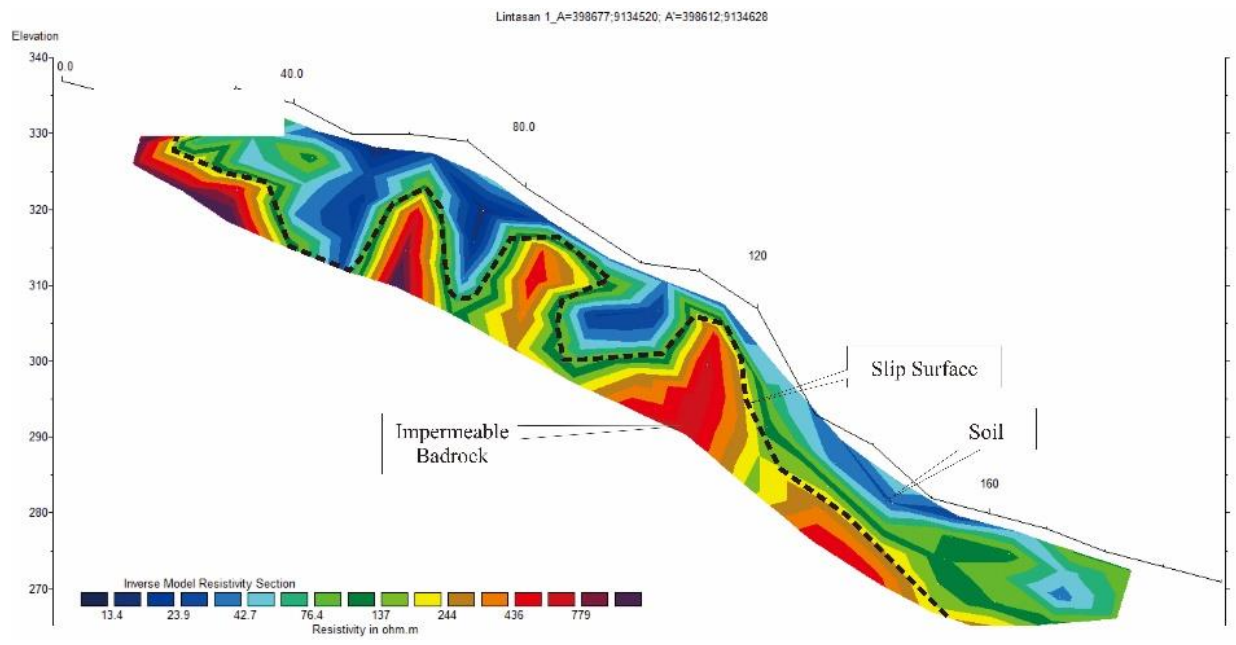

Fig 5. Section of 2D Geoelectric on Resistivity Survey Line 1

Resistivity Survey Line 2 shows that the slip plane is at a distance of $80 \mathrm{~m}$ from the starting point and in the derivative area from an elevation of $280 \mathrm{~m}$ to $260 \mathrm{~m}$ (Fig. 6). The slip plane is at a depth of about $10 \mathrm{~m}$. The slip plane is in the form of igneous rock, namely andesite, shown in red with a resistivity between $424 \Omega \mathrm{m}$ shown on the dashed black line. The resistivity value of 50-190 $\Omega \mathrm{m}$ is the soil marked with a green-orange colour. In contrast, the resistivity of $1.56-30 \Omega \mathrm{m}$ is soil with water saturation.

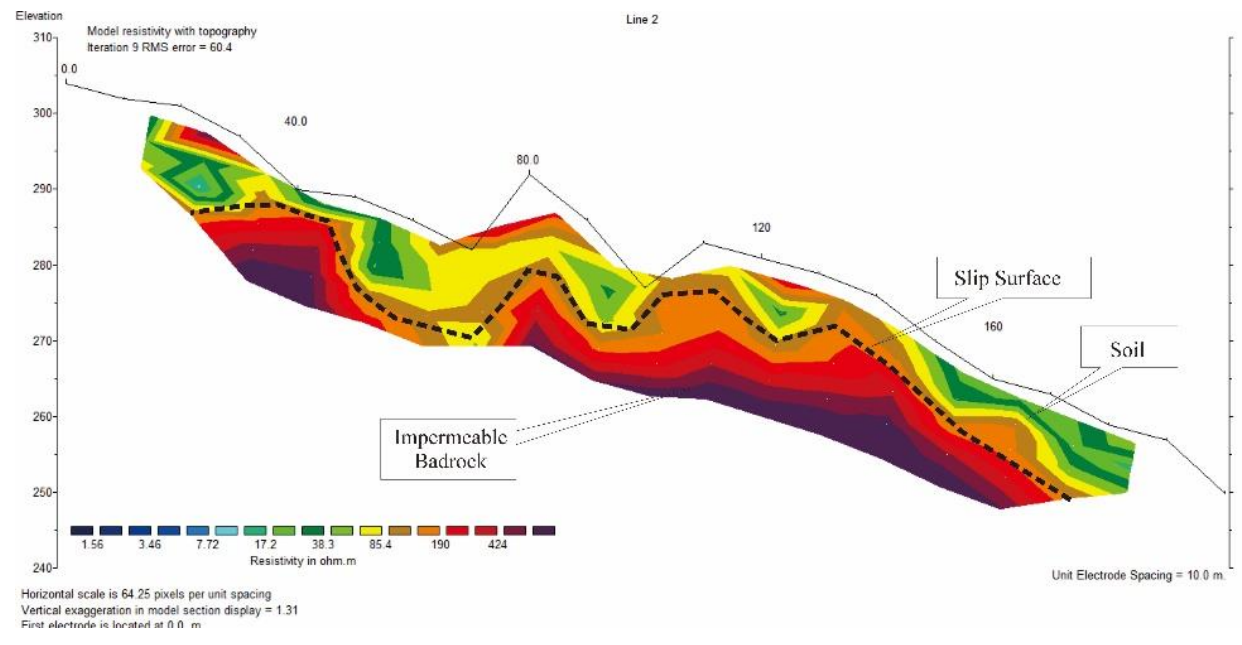

Fig 6. Section of 2D Geoelectric on Resistivity Survey Line 2 
Resistivity Survey Line 3 is a horizontal path used to see horizontal resistivity continuity (Fig. 7). Igneous rock is andesite shown in red, with a resistivity between $429 \Omega \mathrm{m}$ shown in red. The resistivity value of 30-206 $\Omega \mathrm{m}$ is the soil marked with a green-orange colour. In contrast, the resistivity $2.49-15$ $\Omega \mathrm{m}$ is the soil with water pasteurization, indicated by the colour dark blue - light blue.

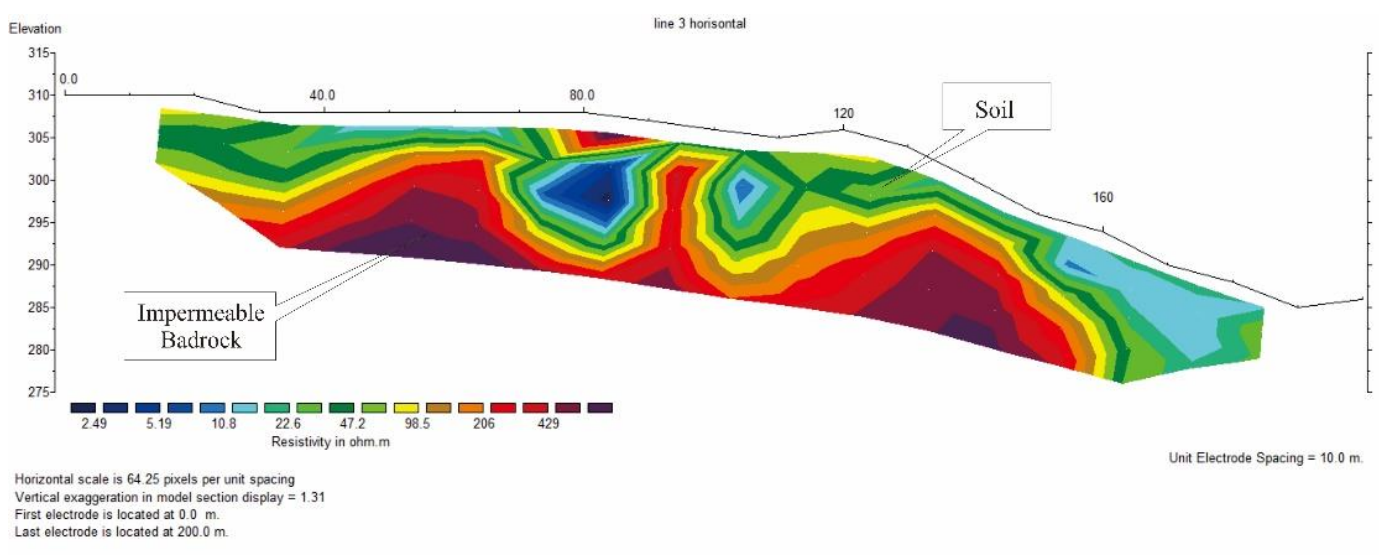

Fig 7. Section of 2D Geoelectric on Resistivity Survey Line 3

Resistivity Survey Line 4 is also a horizontal path used to see the continuity of horizontal resistivity. Igneous rock is andesite shown in red with a resistivity between $400-700 \Omega \mathrm{m}$ shown in pink-red. The resistivity value of $59-200 \Omega \mathrm{m}$ is the soil marked with a green-orange colour. In contrast, the resistivity of $10.4-35 \Omega \mathrm{m}$ is the soil with water pasteurization, indicated by dark blue - light blue colour.

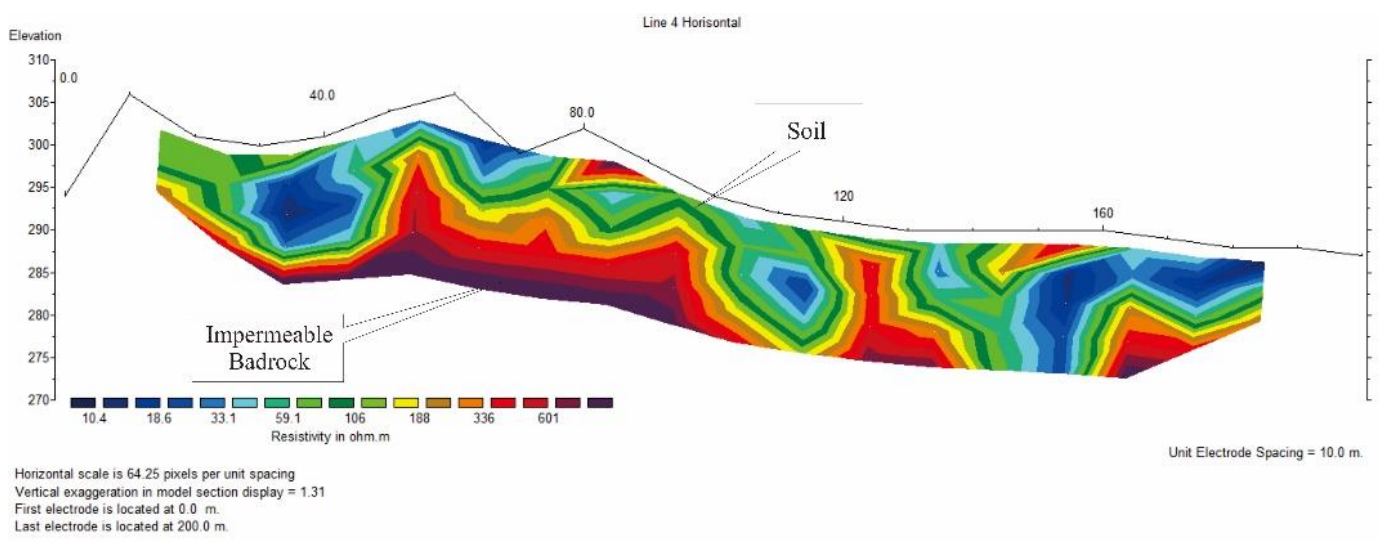

Fig 8. Section of 2D Geoelectric on Resistivity Survey Line 4

Resistivity Survey Line 5 shows that the slip plane is at a distance of $120 \mathrm{~m}$ from the starting point and in the descent area from $270 \mathrm{~m}$ to $240 \mathrm{~m}$ elevation and at a depth of about $10 \mathrm{~m}$. In line 5 , it is dominated by igneous rock. The slip plane is igneous rock shown in red with a resistivity between 668-1600 $\Omega \mathrm{m}$ shown on the dotted black line. The resistivity value of 61-300 $\Omega \mathrm{m}$ is the soil marked with green-orange colour. While the resistivity of $4.01-22.1 \Omega \mathrm{m}$ is soil with water saturation. 


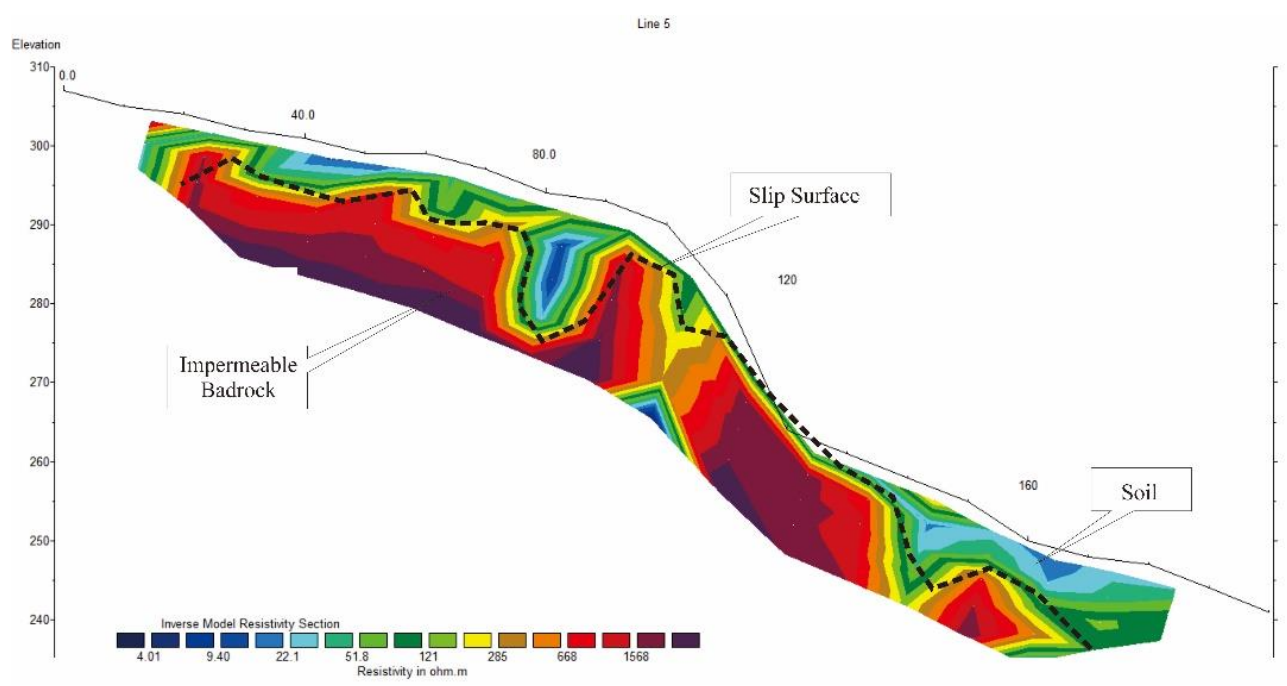

Fig 9. Section of 2D Geoelectric on Resistivity Survey Line 5

In this study, the landslide material is dominated by soil with an average depth of $10 \mathrm{~m}$ and low resistivity between 1-34 $\Omega \mathrm{m}$. Rain occurs during a period so that the soil may be oversaturated by water, indicated by a blue colour on each measurement path. This water saturation makes the potential for landslides increase. The research was also carried out in elevated areas near kiskendo, girimulyo, kulonprogo caves, resulting in the potential for landslides in the form of limestone irrigated by water with 3-25 m [24]. This research also shows that the bedrock is at a depth of about 10-15 m. When rainwater falls and fills the soil during the rainy season, the water in the soil increases and terasturizes [25]. In Kokap District in November 2020, rainfall is above average, namely 277 - 360 mm [12]. With the intensity of rain and a sliding slope of about $40^{\circ}$, the research area has the potential for landslides. Based on this, it is necessary to take further disaster mitigation steps to anticipate casualties.

\section{CONCLUSION AND SUGGESTION}

Based on research with the resistivity method, it was found that the slip surface was in the form of impermeable rock, namely andesite with a resistivity value between $668-1600 \Omega \mathrm{m}$ with an average depth of 10-15 $\mathrm{m}$. while the landslide material is in the form of soil with a resistivity value between 61-300 $\Omega \mathrm{m}$, if the soil is saturated with water, the resistivity value is between $4.01-22.1 \Omega \mathrm{m}$. It is necessary to do further research using the same method but at different times, namely during the rainy season and the dry season.

\section{ACKNOWLEDGMENTS}

Thanks to the editor, reviewers of Jurnal Ilmu Pendidikan Fisika for their review and finally revise the content of the paper greatly and thank to field assistants for collecting data to support this study. This research was fully funded by Direktorat Riset dan Pengabdian Masyarakat Direktorat Jenderal Riset dan Pengembangan Kementerian Riset, Teknologi, dan Pendidikan Tinggi and support by Lembaga Penelitian Pengabdian Masyarakat dan Inovasi (LPPMI)-ITNY.

\section{REFERENCES}

[1] Perrone, A., Lapenna, V., \& Piscitelli, S. (2014). Electrical resistivity tomography technique for landslide investigation: a review. Earth-Science Reviews, 135: 65-82. 
[2] Nordiana, M. M., Azwin, I. N., Nawawi, M. N. M., \& Khalil, A. E. (2018). Slope failures evaluation and landslides investigation using 2-D resistivity method. NRIAG Journal of Astronomy and Geophysics, 7(1): 84-89.

[3] http://vsi.esdm.go.id (5 Maret 2018). Tabel wilayah potensi terjadi Gerakan Tanah di kecamatan Girimulyo, Kabupaten Kulonprogo [Online].

[4] https://regional.kompas.com/read/2020/10/27/18382191/longsor-rusak-tiga-rumah-di-desakalirejo-kulon-progo?page=all. 2020. [Online].

[5] Peruccacci, S., Brunetti, M. T., Gariano, S. L., Melillo, M., Rossi, M., \& Guzzetti, F. (2017). Rainfall thresholds for possible landslide occurrence in Italy. Geomorphology, 290: 39-57.

[6] Šilhán, K., Tichavský, R., Fabiánová, A., Chalupa, V., Chalupová, O., Škarpich, V., \& Tolasz, R. (2019). Understanding complex slope deformation through tree-ring analyses. Science of The Total Environment, 665: 1083-1094.

[7] Perrone, A., Vassallo, R., Lapenna, V., \& Di Maio, C. (2008). Pore water pressures and slope stability: a joint geophysical and geotechnical analysis. Journal of Geophysics and Engineering, 5(3): 323-337.

[8] Abidin, M. H. Z., Madun, A., Tajudin, S. A. A., \& Ishak, M. F. (2017). Forensic assessment on near surface landslide using electrical resistivity imaging (ERI) at Kenyir Lake Area in Terengganu, Malaysia. Procedia engineering, 171: 434-444.

[9] Karcioğlu, G. (2019). Near-surface resistivity structure near avcilar landslide in Istanbul, Turkey by 2D inversion of VLF data. Journal of Applied Geophysics, 163: 73-83.

[10] Loke, M. H. (2015). Tutorial: 2-D and 3-D electrical imaging surveys. www.geotomosoft. com/coursenotes.zip.

[11] Loke, M. H., Acworth, I., \& Dahlin, T. (2003). A comparison of smooth and blocky inversion methods in 2D electrical imaging surveys. Exploration geophysics, 34(3): 182-187.

[12] Badan Meteorologi, (2020). Klimatologi dan Geofisika, "Buletin Prakiraan Curah Hujan September-November 2020 DIY," Stasiun Klimatologi Sleman, Yogyakarta.

[13] Sismanto, S., \& Nasharuddin, N. (2018). Landslide Potential Mapping in Penggung Purwosari Village, District Girimulyo, Kulonprogo, Yogyakarta Province, Indonesia Using Dipole-Dipole Resistivity Method. International Journal of Civil Engineering and Technology, 9(6): 11411150.

[14] Crawford, M. M., Bryson, L. S., Woolery, E. W., \& Wang, Z. (2018). Using 2-D electrical resistivity imaging for joint geophysical and geotechnical characterization of shallow landslides. Journal of Applied Geophysics, 157: 37-46.

[15] Uhlemann, S., Hagedorn, S., Dashwood, B., Maurer, H., Gunn, D., Dijkstra, T., \& Chambers, J. (2016). Landslide characterization using P-and S-wave seismic refraction tomography-The importance of elastic moduli. Journal of Applied Geophysics, 134: 64-76.

[16] Gance, J., Malet, J. P., Supper, R., Sailhac, P., Ottowitz, D., \& Jochum, B. (2016). Permanent electrical resistivity measurements for monitoring water circulation in clayey landslides. Journal of Applied Geophysics, 126: 98-115.

[17] Břežný, M., Pánek, T., Lenart, J., Grygar, R., Tábořík, P., \& McColl, S. T. (2018). Sackung and enigmatic mass movement folds on a structurally-controlled mountain ridge. Geomorphology, 322: $175-187$.

[18] Prastowo, R., Trianda, O., \& Novitasari, S. (2018). Identifikasi Kerentanan Gerakan Tanah Berdasarkan Data Geologi Daerah Kalirejo, Kecamatan Kokap, Kabupaten Kulonprogo, Yogyakarta. Kurvatek, 3(2): 31-40.

[19] Van Bemmelen, R. V. (1949). The Geology of Indonesia. Vol. IA: General Geology of Indonesia and Adjacent Archipelagoes. US Government Printing Office.

[20] Rahardjo, W., \& Sukandarrumidi \& Rosidi, H. (1995). Yogyakarta Sheet Geological Map scale 1: 100.000. Bandung: Geological Research and Development Center.

[21] Kearey, P., Brooks, M., \& Hill, I. (2002). An introduction to geophysical exploration (Vol. 4). John Wiley \& Sons.

[22] Friedel, S., Thielen, A., \& Springman, S. M. (2006). Investigation of a slope endangered by rainfall-induced landslides using 3D resistivity tomography and geotechnical testing. Journal of Applied Geophysics, 60(2): 100-114.

[23] Bellanova, J., Calamita, G., Giocoli, A., Luongo, R., Macchiato, M., Perrone, A., ... \& Piscitelli, 
S. (2018). Electrical resistivity imaging for the characterization of the Montaguto landslide (southern Italy). Engineering Geology, 243: 272-281.

[24] Sismanto, M. D. E., \& Wahyuni, L. T. (2019). Identification Slip Surface Using Resistivity And VLF-R Mode In Goa Kiskendo Yogyakarta Indonesia. International Journal, 16(53): 177-183.

[25] Ling, C., Xu, Q., Zhang, Q., Ran, J., \& Lv, H. (2016). Application of electrical resistivity tomography for investigating the internal structure of a translational landslide and characterizing its groundwater circulation (Kualiangzi landslide, Southwest China). Journal of Applied Geophysics, 131: 154-162. 